\title{
HBV and HCV in Health care workers and students of a newly established Tertiary care hospital at Rishikesh: Prevalence and immunity status
}

Pratima Gupta ${ }^{1}$, Neelam Kaistha ${ }^{2}$, Balramji Omar ${ }^{3}$

${ }^{1}$ Professor, Department of Microbiology, All India Institute of Medical Sciences, Rishikesh, Uttarakhand; ${ }^{2}$ Professor, Department of Microbiology, All India Institute of Medical Sciences, Rishikesh, Uttarakhand; ${ }^{3}$ Additional Professor, Department of Microbiology, All India Institute of Medical Sciences, Rishikesh, Uttarakhand

\begin{tabular}{|c|c|c|c|c|c|c|c|}
\hline \multicolumn{2}{|c|}{\begin{tabular}{l|l} 
Abstract & Introduction \\
\end{tabular}} & Methodology & $\underline{\text { Results }}$ & Conclusion & References & Citation & Tables / Figures \\
\hline \multicolumn{8}{|c|}{ orrespon } \\
\hline \multicolumn{7}{|c|}{$\begin{array}{l}\text { Dr Pratima Gupta, Professor, Department of Microbiology, All India Institute of Medical Sciences, Rishikesh, } \\
\text { Uttarakhand } \\
\text { E Mail ID: } \underline{\text { drpratima68@gmail.com }}\end{array}$} & 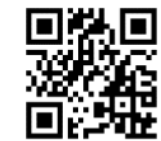 \\
\hline
\end{tabular}

\section{Citation}

Gupta P, Kaistha N, Omar B. HBV and HCV in Health care workers and students of a newly established Tertiary care hospital at Rishikesh: Prevalence and immunity status. Indian J Comm Health. 2020;32(2):454-457.

Source of Funding: AlIMS Rishikesh Conflict of Interest: None declared

\section{Article Cycle}

Received: 21/05/2020; Revision: 02/06/2020; Accepted: 13/06/2020; Published: 30/06/2020

This work is licensed under a Creative Commons Attribution 4.0 International License.

\section{Abstract}

Background: Hepatitis $B$ and $C$ cause serious infectious disease of the liver which affects millions of people worldwide. More than 2 billion people living today have been infected with Hepatitis B virus (HBV) at some time in their lives and about 350 million people are carriers of the virus. Aim: To detect HBV and HCV infection and assess HBV immunity status amongst healthcare workers, medical students and nursing students at AIIMS Rishikesh. Methods: 135 participants (Medical faculty, Nursing Faculty, Resident Doctors, laboratory technicians, laboratory attendants, medical and nursing students) were enrolled for the study. Serological tests HBsAg, anti-hepatitis C virus antibodies (anti-HCV), anti-HBs antibodies, were performed. None were positive for HBsAg 1.5\% were positive for Anti HCV antibodies and $61.75 \%$ had protective levels of antiHBs. Conclusion: HBV vaccination and screening for HBV, HCV, and anti-HBs of all HCW and students at time of entry should be done. Yearly screening thereafter should be done to check as follow up. Regular training on HBV vaccination and safe practices should be emphasized at all levels of HCW.

\section{Keywords}

$\mathrm{HBV}$; HCV; Anti HBs; Health care workers

\section{Introduction}

Hepatitis B and C are most common causative agents of chronic hepatitis, which are asymptomatic in most individuals and can lead to liver cell failure and hepatocellular carcinoma. Frequency of exposure of HCW to HBV is influenced by HBV endemicity. Thus, $90 \%$ of such HBV infections occur in Asia and Africa. (1)

Hospitals in these countries are overburdened, and HCW provide service to large populations with $\mathrm{HBV}$ carrier rates of $5-10 \%$. More than $70 \%$ of HCW in hyper or intermediate endemic countries have been reported to have needle stick injuries, with an average of two needle pricks a year and four needle pricks during their active professional life. However, less than $30 \%$ of needle stick injuries were reported to appropriate authorities. $(2,3,4,5)$

The study was planned to help us to detect HBV and HCV infection and also to ascertain the HBV vaccination status and immune status of healthcare workers, medical students and nursing students. Since AlIMS Rishikesh is an upcoming Tertiary care hospital, there is an urgent need to develop a policy for vaccination, surveillance and post exposure management protocol for not only HBV but other blood borne viral diseases in healthcare workers and students who are at risk for occupational exposures to these infections. This policy would furthermore reduce risk of transmission these infections to not only health care workers but also to patients.

\section{Aims \& Objectives}

Aim: To detect HBV and HCV infection and assess HBV immunity status amongst healthcare workers, medical students and nursing students at AlIMS Rishikesh.

Objectives: To screen for HBsAg and anti HCV antibodies in healthcare workers, medical students and nursing students. 
1. To assess Hepatitis $B$ infection status, $\mathrm{HBV}$ vaccination and Immunity status.

2. To assess the status of HBV infection and vaccination status amongst healthcare workers.

\section{Material \& Methods}

This study was conducted in the Department of Microbiology, AllMS Rishikesh. Hundred and 135 participants were enrolled for the study. Participants consisted of Medical faculty, Nursing Faculty, Resident Doctors, laboratory technicians, laboratory attendants, medical and nursing students. After obtaining an informed written consent from each participant, they were asked to complete a questionnaire consisting of their age, gender, Hepatitis B vaccination status, their job description, past history of occupational exposure to blood and body fluids and educational level.

Blood sample was drawn from each participant under strict aseptic precautions in a plain vacutainer. Blood was allowed to clot and serum separated and stored at $-8 \circ \mathrm{C}$ until further testing. Serological tests (HBsAg, antihepatitis $\mathrm{C}$ virus antibodies (anti-HCV), anti-HBs antibodies, were performed using commercially available ELISA kits according to the manufacturer's instructions. Anti-HBs titers of $>10 \mathrm{mIU} / \mathrm{mL}$ was considered protective. After serological evaluation individual recommendations were made for HBV vaccination. The following policies were drafted:

- Post exposure management for occupational exposures to blood and body fluids which would ensure first aid, prophylactic drugs, active and passive immunization, serological and clinical follow up of affected individual.

- HBV vaccination and screening for anti HBs antibodies titers in all categories of health care workers.

\section{Results}

The overall prevalence of $\mathrm{HBsAg}$ and anti $\mathrm{HCV}$ in health care workers and students was found to be $0 \%$ and $1.5 \%$ respectively. (Table 1)

The only student found to be anti HCV positive was in her first semester, and was not vaccinated against hepatitis $B$ and had anti-HBs titers less than $10 \mathrm{lU} / \mathrm{L}$. It is possible that the HCV positivity in this case might be due to unknown risk factors other than those associated with the profession of HCWs. The possibility of a chronic carrier state in this student cannot be ruled out since this was detected within the first semester of her admission in the healthcare setup. One of the resident doctor who was found to be HCV positive gave history of Road traffic accident 7 years back and had received blood transfusion from a private nursing home. He was asymptomatic till now. HCV RNA PCR was done and 50,000 HCV RNA copies/ml were detected and he was put on Daclatasvir and Sofosbuvir for 12 weeks. After completion of course HCV RNA PCR was repeated and no copies were detected. (Table 2)

\section{Discussion}

Prior to the availability of the hepatitis B vaccine, numerous cross-sectional surveys showed that HCWs had a three to five-fold higher seroprevalence of HBV infection than the general U.S. population. Prevalence rates of HBV infection of 13 to $18 \%$ have been demonstrated among surgeons and infection rates up to $27 \%$ have been demonstrated among dentists and oral surgeons in comparison to about $4 \%$ of first-time blood donors. Seroprevalence surveys among hospital-based HCWs in western countries have found rates of anti-HCV similar to $(0.5 \%)$ or lower than those estimated to occur in the general population. (6)

Since tests for Hepatitis-B surface antigen (HBsAg) and anti-HBs have become available; world-wide studies on healthcare professionals have indicated that the prevalence of $\mathrm{HBsAg}, \mathrm{HCV}$ and anti-HBs varies from $0-15 \%$, $1-2 \%$ and $15-70 \%$ respectively. $(7,8,9)$

India has been categorized as having intermediate endemicity of HBV with $2-4 \% \mathrm{HBsAg}$ prevalence in general population. Health care workers fall into high risk group, but none were detected in our study population which is in spite of the fact that this group was not fully HBV vaccinated. In a recent study from Mumbai in 2017, out of 1347 hospital staffs, $0.4 \%$ were $\mathrm{HBsAg}$ positive and $0.1 \%$ were anti HCV positive. Only $54 \%$ had complete HBV vaccine coverage. (10)

Earlier Indian studies have reported HBV infection rates among HCW to be $10 \%$ in $1992,2.21 \%$ in $1998,11.7 \%$ in $2006,1 \%$ in 2008 and $0.4 \%$ in 2010 . $(7,11,12,13,14)$ This decreasing trend is most probably due to increasing awareness regarding these infections and hepatitis $B$ vaccination.

Out of 37 doctors, 32 were fully vaccinated and only one was a non-responder, in nursing staff out of 18 none had taken HBV vaccination but $38.9 \%(7)$ had protective antiHBs levels. Six students were fully vaccinated and all had protective levels of antibodies and 5 out of $8(62.5 \%)$ who were partially vaccinated had protective levels of anti HBs, and $50 \%$ of students who could remember vaccination status or had no vaccination history had protective levels of anti HBs. Similarly, all lab technicians and attendants who were vaccinated had protective levels of anti HBs and 4 out of $14(28.6 \%)$ who could not give vaccination history had protective levels of anti HBs.

A study in PGIMER Chandigarh showed that majority of the nursing students, i.e. $75.2 \%$ (188/250), were not vaccinated or vaccination status was not known. Of the ones who had received a complete course of HBV vaccination, $82.2 \%(51 / 62)$ showed protective levels. The anti-HBs antibody levels in students who were unvaccinated or where vaccination status was not known was 36\% (17/47) and 29\% (42/141) respectively. As per their history sheets, none of these students had any previous suffering due to hepatitis (14). Hence it can be 
deduced that unvaccinated group in our study may have developed the anti-HBs antibody due to subclinical infection/exposure like that noticed by Singh et al (14)

\section{Conclusion}

$\mathrm{HBV}$ vaccination and screening for $\mathrm{HBV}, \mathrm{HCV}$, and antiHBs of all HCW and students at time of entry should be done. Yearly screening thereafter should be done to check as follow up. Regular training on HBV vaccination and safe practices should be emphasized at all levels of HCW.

\section{Recommendation}

1. HBV vaccination policy to be implemented. All nonvaccinated, non-responders, without protective levels of antiHBs should be vaccinated.

2. Screening for HBV, HCV, and antiHBs of all HCW at time of entry should be made mandatory and if no antiHbs is detected vaccination should be done

3. HBV, HCV, and anti HBs levels should be monitored yearly for HCW's.

4. Students should be screened at time of admission to college.

5. PEP policy to be implemented (testing source patient and HCW and administration of PEP drug, Nodal officer-Microbiologist for testing and maintaining Registry, and referral to Physician for medication). Medicine to be kept in Medicine OPD and Emergency.)

6. Regular 6 monthly Training on UWP to all staff and students (funds to be allotted for same).

7. Set up ICTC center- Area, personnel, PEP drugs.

\section{Limitation of the study}

Screening for anti $\mathrm{HBC}$ and HIV antibodies could give additional information

\section{Relevance of the study}

It shows that $\mathrm{HBV}$ vaccination has brought down levels of HBV infections.

\section{Authors Contribution}

All authors have contributed equally.

\section{References}

1. Leshmana LA, Leung NWY, Mahachai V, Phiet PH, Suh DJ, Yao G, H. Zhuang. Hepatitis B: overview of the burden of disease in the AsiaPacific region. Liver Int. 2006; 26: 3-10.

2. Gurubacharya DL, Mathura KC, Karki DB. Knowledge, attitude and practices among health care workers on needle-stick injuries.
Kathmandu Univ Med J (KUMJ). 2003 Apr-Jun;1(2):91-4. PubMed PMID: 16388204.[PubMed].

3. Zafar A, Aslam N, Nasir N, Meraj R, Mehraj V. Knowledge, attitudes and practices of health care workers regarding needle stick injuries at a tertiary care hospital in Pakistan. J Pak Med Assoc. 2008 Feb;58(2):57-60. PubMed PMID: 18333520.[PubMed].

4. Kermode $M$, Jolley $D$, Langkham B, Thomas MS, Crofts $N$. Occupational exposure to blood and risk of bloodborne virus infection among health care workers in rural north Indian health care settings. Am J Infect Control. 2005 Feb;33(1):34-41. doi: 10.1016/j.ajic.2004.07.015. PubMed PMID: 15685133. [PubMed].

5. Sadoh WE, Fawole AO, Sadoh AE, Oladimeji AO, Sotiloye OS. Practice of universal precautions among healthcare workers. J Natl Med Assoc. 2006 May;98(5):722-6. PubMed PMID: 16749647; PubMed Central PMCID: PMC2569287.[PubMed].

6. Sadoh $W E$, Fawole $A O$, Sadoh $A E$, Oladimeji $A O$, Sotiloye $O S$. Practice of universal precautions among healthcare workers. J Natl Med Assoc. 2006 May;98(5):722-6. PubMed PMID: 16749647; PubMed Central PMCID: PMC2569287.[PubMed]

7. Sukriti, Pati NT, Sethi A, Agrawal K, Agrawal K, Kumar GT, Kumar M, Kaanan AT, Sarin SK. Low levels of awareness, vaccine coverage, and the need for boosters among health care workers in tertiary care hospitals in India. J Gastroenterol Hepatol. 2008 Nov;23(11):1710-5. doi: 10.1111/j.1440-1746.2008.05483.x. Epub 2008 Aug 28. PubMed PMID: 18761556.[PubMed]

8. Kondili LA, Ulqinaku $D$, Hajdini $M$, Basho $M$, Chionne $P$, Madonna E, Taliani G, Candido A, Dentico P, Bino S, Rapicetta M. Hepatitis $B$ virus infection in health care workers in Albania: a country still highly endemic for HBV infection. Infection. 2007 Apr;35(2):94-7. doi: 10.1007/s15010-007-6076-1. PubMed PMID: 17401713.[PubMed]

9. Ozsoy MF, Oncul O, Cavuslu S, Erdemoglu A, Emekdas G, Pahsa A. Seroprevalences of hepatitis $B$ and $C$ among health care workers in Turkey. J Viral Hepat. 2003 Mar;10(2):150-6. doi: 10.1046/j.13652893.2003.00404.x. PubMed PMID: 12614472.[PubMed].

10. Shah DK, Jain SS, Khot AA, Gharat AR, Rajadhyaksha GC, RathiPM. Low prevalence of hepatitis $B$ and $C$ infections among the healthcare workers despite low vaccination coverage for hepatitis B in Mumbai. Indian J Med Sci 2017;69:8-12

11. Duseja A, Arora L, Masih B, Singh H, Gupta A, Behera D, Chawla YK, Dhiman RK. Hepatitis B and C virus--prevalence and prevention in health care workers. Trop Gastroenterol. 2002 Jul-Sep;23(3):125-6. PubMed PMID: 12693154.[PubMed]

12. Shinde SV, Puranik GV. A study screening of blood donors for blood transmissible diseases. Indian J Hematol Blood Transfus 2007:23;99 103.

13. Shinde SV, Puranik GV. A study-screening of blood donors for blood transmissible diseases. Indian J Hematol Blood Transfus. 2007 Dec;23(3-4):99-103. doi: 10.1007/s12288-008-0006-y. Epub 2008 Mar 19. PubMed PMID: 23100924; PubMed Central PMCID: PMC3453123.[PubMed].

14. Singh G, Singh MP, Walia I, Sarin C, Ratho RK. Screening for hepatitis $B$ and $C$ viral markers among nursing students in a tertiary care hospital. Indian J Med Microbiol. 2010 Jan-Mar;28(1):78-9. doi: $\quad 10.4103 / 0255-0857.58740$. PubMed PMID: 20061775. [PubMed]

\section{Tables}

TABLE 1 HBSAG STATUS IN HEALTHCARE WORKERS

\begin{tabular}{|l|l|l|l|l|}
\hline Category & Total & HBsAg positive & Anti HCV positive & Anti Hbs positive (>10 IU/Lt) \\
\hline Doctors & 37 & 0 & $1(2.7 \%)$ & $32(82.1 \%)$ \\
\hline Nurses & 18 & 0 & 0 & $07(38.9 \%)$ \\
\hline Students & 60 & 0 & $1(1.67 \%)$ & $34(56.7 \%)$ \\
\hline Lab attendants and Technicians & 20 & 0 & 0 & $10(50 \%)$ \\
\hline TOTAL & 135 & 0 & $2(1.5 \%)$ & $83(61.5 \%)$ \\
\hline
\end{tabular}


TABLE 2 RELATION OF PROTECTIVE LEVELS OF ANTI-HBS ANTIBODIES WITH VACCINATION STATUS IN HEALTHCARE WORKERS

\begin{tabular}{|c|c|c|c|c|c|c|}
\hline Category & $\begin{array}{l}\text { Total Anti } \\
\text { Hbs } \\
\text { negative }\end{array}$ & Total & Doctors & Nurses & Students & $\begin{array}{l}\text { Lab } \\
\text { attendants/ } \\
\text { Technicians }\end{array}$ \\
\hline & & Anti Hbs positive & $\mathbf{N}=37$ & $\mathrm{~N}=18$ & $\mathrm{~N}=60$ & $\mathrm{~N}=\mathbf{2 0}$ \\
\hline Completed HBV Vaccination (3 doses) & 1 & 30 & $23(76.7 \%)$ & 0 & 3 & 4 \\
\hline $\begin{array}{l}\text { Completed HBV Vaccination + Booster } \\
\text { dose }\end{array}$ & 0 & 13 & $9(69.2 \%)$ & 0 & 3 & 1 \\
\hline HBV Vaccination ( 2 doses) & 1 & 4 & 0 & 0 & 3 & 1 \\
\hline HBV Vaccination (1 doses) & 3 & 2 & 0 & 0 & 2 & 0 \\
\hline Non HBV Vaccinated/not known & 47 & 34 & 0 & 7 & 23 & 4 \\
\hline TOTAL & 52 & $83(61.5 \%)$ & $32(86.5 \%)$ & $7(38.9 \%)$ & $34(56.7 \%)$ & $10(50 \%)$ \\
\hline
\end{tabular}

